\title{
DUKUNGAN SUAMI UNTUK MELAKSANAKAN PROGRAM PERENCANAAN PERSALINAN DAN PENCEGAHAN KOMPLIKASI (P4K) (STUDI LITERATUR)
}

\author{
HalimahTusyadiah ${ }^{1}$, Rohani ${ }^{2}$ \\ Prodi DIII Kebidanan STIKES Mitra Adiguna \\ Jl. Kenten Permai Blok J No 9-12 Bukit Sangkal Palembang \\ ghinakiyasah@gmail.com
}

\begin{abstract}
Abstrak
Dukungan keluarga atau orang terdekat terutama suami kepada ibu hamil untuk mendukung tujuan P4K sangat dibutuhkan. Dalam hal ini suami berperan aktif untuk memotivasi ibu hamil untuk memeriksakan kehamilannya ke tenaga kesehatan untuk mendapatkan pelayanan. Tujuan penelitian ini mengetahui dan membandingkan semua teori-teori dari buku maupun jurnal yang berkaitan dengandukungan suami untuk melaksanakan program Perencanaan Persalinan dan Pencegahan Komplikasi (P4K). Desain penelitian ini adalah menggunakan metode studi literatur.Sumber data dalam penelitian ini menggunakan data sekunder yang didapat dengan melakukan studi literatur dari jurnaljurnal yang sesuai dengan topik penelitian dari tahun 2013-2020 sebanyak 10 jurnal. Berdasarkan hasil literatur review yang dilakukan oleh penulis, dapat disimpulkan bahwa dari hasil literatur review diketahui bahwa dukungan suami kepada ibu hamil terhadap program P4K ini masih kurang, hal ini karena mayoritas suami adalah bekerja di luar rumah sehingga tidak memiliki waktu untuk mengantarkan istrinya periksa kehamilan ke bidan serta kurang memperhatikan kondisi kesehatan istrinya. Sebagian besar ibu hamil dan suami merencanakan persalinannya pada saat mendekati waktu persalinan. Saran diharapkan tenaga kesehatan dapat mengoptimalkan pemberian informasi kepada ibu hamil tentang Program Perencanaan Persalinan dan Pencegahan Komplikasi (P4K) pada saat ibu hamil memeriksakan kehamilannya dan dilakukan secara rutin sehingga ibu hamil akan selalu mengingatnya.

Kata Kunci : Dukungan Suami, Program Perencanaan Persalinan dan Pencegahan Komplikasi (P4K)
\end{abstract}

\begin{abstract}
Support from family or closest people, especially husbands, to pregnant women to support P4K goals is very much needed. In this case, the husband plays an active role in motivating pregnant women to have their pregnancy checked by health workers for services. The purpose of this study is to find out and compare all theories from books and journals related to the husband's support to carry out the Maternity Planning and Complications Prevention (P4K) program. The design of this research is to use the literature study method. Sources of data in this study use secondary data obtained by conducting literature studies from journals that are in accordance with the research topic from 2013-2020 as many as 10 journals. Based on the results of the literature review conducted by the author, it can be concluded that from the results of the literature review it is known that the husband's support for pregnant women for the P4K program is still lacking, this is because the majority of husbands work outside the home so they do not have time to take their wives to check for pregnancy. midwives and paid less attention to the health condition of their wives. Most of the pregnant women and their husbands plan their delivery near the time of delivery. Suggestions are expected that health workers can optimize the provision of information to pregnant women about the Maternity Planning and Complication Prevention Program (P4K) when pregnant women have their pregnancy checked and carried out regularly so that pregnant women will always remember it.
\end{abstract}

Jurnal Kesehatan dan Pembangunan, Vol.10, No.20, Juli 2020 


\section{PENDAHULUAN}

Program Perencanaan Persalinan dan Pencegahan Komplikasi (P4K) merupakan salah satu upaya pemerintah dalam menurunkan Angka Kematian Ibu (AKI) di Indonesia. Upaya program $\mathrm{P} 4 \mathrm{~K}$ sudah dimulai sekitar tahun 2010. P4K adalah merupakan suatu kegitan yang difasilitasi oleh Bidan di desa dalam rangka meningkatkan peran aktif suami, keluarga dan masyarakat dalam merencanakan persalinan yang aman dan persiapan menghadapai komplikasi bagi ibu hamil (Kamidah, 2018).

Ancaman kematian maternal masih menjadi masalah utama di negara berkembang termasuk Indonesia. Berdasarkan data World Health Organization (WHO) sebanyak 830 wanita hamil dan melahirkan meninggal setiap harinya dan terbesar terjadi di negara berkembang, seperti negara di kawasan Afrika, Haiti, Guyana, Bolivia, Nepal, Myanmar, India dan Indonesia (Nurrizka, 2018).

Indonesia termasuk negara yang mengalami peningkatan angka kematian maternal. Berdasarkan Hasil Survei Demografi dan Kesehatan Indonesia (SDKI) tahun 2012 terjadi peningkatan angka kematian maternal atau Angka Kematian Ibu (AKI) dari 228 per 100.000 kelahiran hidup pada tahun 2007 menjadi 359 per 100.000 kelahiran hidup. Angka tersebut jauh dari target MDGs tahun 2015 sebesar 102 per 100.000 kelahiran hidup pada 2015. Dari kondisi tersebut, perlu upaya keras dari pemerintah untuk mengatasi masalah kematian maternal agar target Sustainable Development Goals (SDGs) sebesar 70 per 100.000 kelahiran hidup pada 2030 bisa dicapai (Nurrizka, 2018).

Angka kematian Ibu untuk Provinsi Sumatera Selatan tahun 2018 sebesar 119.
Jumlah kematian ibu melahirkan selama 3 tahun terakhir mengalami penurunan namun sedikit meningkat pada tahun 2018. Jumlah kematin ibu tahun 2014 sebanyak 155 orang, naik menjadi 164 orang kematian pada tahun 2015, turun menjadi 142 orang pada tahun 2016 dan turun lagi menjadi 107 orang tahun 2017 dan naik menjadi 119 orang pada tahun 2018. Jumlah Kematian Ibu melahirkan tahun 2018 tertinggi terjadi di kabupaten Banyuasin sebanyak 15 orang, kabupaten Musi Banyuasin sebanyak 13 orang dan kabupaten Musi Rawas sebanyak 12 orang, Sedangkan jumlah kematian ibu maternal terendah terjadi di kota Prabumuli sebanyak 1 orang, kota Pagar Alam sebanyak 2 orang, kabupaten Empat Lawang sebanyak 3. Adapun penyebab terbesar kematian ibu melahirkan di Sumatera Selatan adalah Perdarahan dan Hipertensi (Dinkes Provinsi Sumatera Selatan, 2019).

Berdasarkan data Dinas Kesehatan Kota Palembang, jumlah kematian ibu tahun 2018 di Kota Palembang, Jumlah kematian ibu di Kota Palembang berdasarkanlaporan sebanyak 7 orang dari 27.876 kelahiran hidup. Penyebabnya kematianterbanyak adalah hipertensi dalam kehamilan $72 \%$ (5 orang), danterendah adalah perdarahan $14 \%$ (1 orang). Sedangkan penyebabkematian ibu lainnya adalah gangguan metabolik (DM) yaitu sebanyak 1 (satu) orang (Dinkes Kota Palembang, 2018).

Angka Kematian Ibu (AKI) mencerminkan risiko yang dihadapi ibu-ibu selama kehamilan dan melahirkan yang dipengaruhi oleh status gizi ibu, keadaan sosial ekonomi, keadaan kesehatan yang kurang baik menjelang kehamilan, kejadian berbagai komplikasi pada kehamilan dan kelahiran, serta penggunaan fasilitas pelayanan kesehatan termasuk pelayanan prenatal dan obstetri. Tingginya angka 
kematian ibu menunjukkan keadaan sosial ekonomi yang rendah dan fasilitas pelayanan kesehatan termasuk pelayanan prenatal dan obstetri yang rendah pula (Sari, 2016).

Kematian ibu biasanya terjadi karena tidak mempunyai akses ke pelayanan kesehatan ibu yang berkualitas, terutama pelayanan kegawatdaruratan tepat waktu yang dilatarbelakangi oleh terlambat mengenal tanda bahaya dan mengambil keputusan, terlambat mencapai fasilitas kesehatan, serta terlambat mendapatkan pelayanan di fasilitas kesehatan. Selain itu penyebab kematian maternal juga tidak terlepas dari kondisi ibu itu sendiri dan merupakan salah satu dari kriteria 4 "terlalu", yaitu terlalu tua pada saat melahirkan $(>35$ tahun), terlalu muda pada saat melahirkan (4 anak), terlalu rapat jarak kelahiran/paritas (Sari, 2016).

Pengetahuan ibu hamil menentukan kepatuhan dalam melaksanakan Program Perencanaan Persalinan dan Pencegahan Komplikasi (P4K). Pengetahuan ibu hamil tentang $\mathrm{P} 4 \mathrm{~K}$ adalah segala sesuatu yang diketahui oleh perempuan yang sedang hamil tentang perencanaan persalinan untuk mengoptimalisasi kesehatan mental fisik ibu hamil sehingga mampu menghadapi persalinan, kala nifas, persiapan memberi ASI dan kembalinya kesehatan reproduksi secara wajar. Semakin meningkatnya pengetahuan ibu hamil akan diikuti peningkatan kepatuhan melaksanakan P4K, sebaliknya semakin rendah pengetahuan ibu hamil maka kepatuhannya juga semakin rendah. Hal ini menuntut para tenaga kesehatan untuk memberikan informasi yang lengkap tentang pentingnya P4K (Pramasanthi, 2016).

Dukungan keluarga atau orang terdekat terutama suami kepada ibu hamil untuk mendukung tujuan $\mathrm{P} 4 \mathrm{~K}$ sangat dibutuhkan. Dalam hal ini suami berperan aktif untuk memotivasi ibu hamil untuk memeriksakan kehamilannya ke tenaga kesehatan untuk mendapatkan pelayanan. Orang yang paling penting bagi ibu hamil adalah suami. Dukungan dapat diberikan suami untuk merencanakan persalinan, ikut mewaspadai adanya komplikasi dan tandatanda bahaya dan bersama-sama mempersiapkan suatu rencana apabila terjadi komplikasi (Riani, 2016).

Berdasarkan hasil penelitian Pramasanthi (2013) yang berjudul hubungan pengetahuan ibu hamil dan dukungan suami dengan kepatuhan melaksanakan program perencanaan persalinan dan pencegahan komplikasi (P4K) di Kota Salatiga. Berdasarkan hasil penelitian didapatkan pengetahuan ibu kurang sebanyak 78 responden $(38,2 \%)$ dan pengetahuan ibu baik sebanyak 126 responden $(61,8 \%)$, dukungan suami kurang sebanyak 94 responden $(46,1 \%)$ dan dukungan suami baik sebanyak 110 responden $(53,9 \%)$, sedangkan respnden yang tidak patuh terhadap $\mathrm{P} 4 \mathrm{~K}$ sebanyak 50 respnden $(50 \%)$ dan responden yang patuh terhadap P4K sebanyak 50 responden (50\%). Hasil uji statistik didapatkan ada hubungan antara pengetahuan ibu hamil ( $\mathrm{p}$ value $=$ 0,014 ) dan dukungan suami ( $\mathrm{p}$ value $=0,000$ ) dengan kepatuhan dalam melaksanakan P4K di Kota Salatiga.

Berdasarkan hasil penelitian Lestari (2017) yang berjudul hubungan pengetahuan ibu hamil tentang program perencanaan persalinan dan pencegahan komplikasi dengan pemilihan tempat persalinan di Desa Pisang Kecamatan Patianrowo Kabupaten Nganjuk. Hasil penelitian didapatkan sebagian besar pengetahuan responden berada kategori Cukup yaitu 24 responden (75\%), Pengetahuan baik yaitu 4 responden $(12,5 \%)$, dan Kurang yaitu 4 responden (12,5\%). Data dianalisis dengan SPSS menggunakan Spearman Rank Test dengan $\alpha$ 0,05 Ordonansi dan memperoleh hasil $\rho$ $0,034>0,05$ yang berarti ada hubungan 
pengetahuan ibu hamil tentang program perencanaan kelahiran dan pencegahan komplikasi dengan pemilihan tempat kelahiran di desa dari Patianrowo kecamatan Banana Nganjuk.

Dari data di atas maka peneliti mengunakan studi pustaka untuk mengetahuidukungan suami untuk melaksanakan program Perencanaan Persalinan dan Pencegahan Komplikasi (P4K).

\section{METODE PENELITIAN}

\section{Fokus Penelitian}

Fokus penelitian ini menggunakan literatur review yaitu serangkaian penelitian yang berkenaan dengan metode pengumpulan data pustaka atau penelitian yang objek penelitiannya digali melalui beragam informasi kepustakaan (buku, ensiklopedia, jurnal ilmiah, koran, majalah dan dokumen).

\section{Pengumpulan Data}

Data yang digunakan dalam penelitian ini berasal dari hasil-hasil penelitian yang sudah dilakukan dan diterbitkan dalam jurnal online nasional dan internasional. Dalam melakukan penelitian ini peneliti melakukan pencarian jurnal penelitian yang dipublikasikan di internet menggunakan search engine google scolar dengan kata kunci pengetahuan ibu hamil, dukungan suami, kepatuhan, Program Perencanaan Persalinan dan Pencegahan Komplikasi (P4K).

\section{Situasi Sosial}

Dalam penelitian ini, menggunakan studi pustaka dimana tujuannya untuk memperoleh dukungan teoritis terhadap masalah penelitian yang dipilih, maka peneliti perlu banyak membaca buku, baik berupa teks (teori), maupun hasil penelitian orang lain, majalah, jurnal, dan sebagainya.

\section{Metode Analisis Data}

Buku/Jurnal penelitian yang sesuai dengan kriteria iklusi kemudian dikumpulkan dan dibuat ringkasan buku/jurnal meliputi nama penulis/peneliti, tahun terbit jurnal, rancangan studi, tujuan penelitian, sampel, instrumen (alat ukur) dan ringkasan hasil atau temuan. Ringkasan buku/jurnal penelitian tersebut dimasukan kedalam tabel diurutkan sesuai alfabet dan tahun terbit jurnal dan sesuai dengan format tersebut diatas. Untuk lebih memperjelas analisis abstrak dan full teks jurnal dibaca dan dicermati. Ringkasan buku/jurnal tersebut kemudian dilakukan analisis terhadap isi yang terdapat dalam tujuan penelitian dan hasil / temuan penelitian. Metode analisis yang digunakan menggunakan analisis isi buku/jurnal

\section{HASIL DAN PEMBAHASAN}

\section{Perbandingan Jurnal Lestari (2017) dan Jurnal Melati (2012)}

Perbandingan antara kedua jurnal tersebut diatas memiliki perbedaan dimana dalam jurnal Lestari ingin mencari tahu ada tidaknya hubungan pengetahuan ibu hamil tentang program perencanaan persalinan dan pencegahan komplikasi dengan pemilihan tempat persalinan. Dalam jurnal Lestari dijelaskan bahwa program perencanaan persalinan dan pencegahan komplikasi yang dicanangkan pemerintah bertujuan memantau kehamilan menuju persalinanyang aman dan selamat dan sasarannya adalah seluruh ibu hamil. IndikatorP4K adalah dengan pemasangan stiker $\mathrm{P} 4 \mathrm{~K}$ yang terdiri dari penolong persalinan, tempat persalinan, pendamping persalinan, transportasi, dan 
calonpendonor darah. Karena semua ibu hamil yang telah diberi stiker dapatterpantau oleh semua komponen masyarakat, suami, keluarga dan bidansecara tepat dan cepat. Target yang ingin dicapai dalam $\mathrm{P} 4 \mathrm{~K}$ dimulai dengan dilakukanpemantaun pada sasaran dengan resiko tinggi, sedang dan rendah secaralangsung dengan harapan komplikasi dapat dicegah dan diatasi secara diniDeteksi dini faktor resiko dalam kehamilan. Deteksi dini hamil adalah suatukegiatan pengenalan secara proaktif pada ibu hamil untuk menemukan adanyamasalah atau faktor resiko yaitu deteksi dini ibu hamil biasa dilakukan olehtenaga kesehatan ataupun swadaya masyarakat. Tujuan program perencanaan persalinandan pencegahan komplikasi adalah : Untuk meningkatkan cakupan dan mutu kesehatan bagi ibuhamil dan bayi baru lahir melalui peningkatan peran aktif keluargadan masyarakat dalam rangka merencanakan persalinan yang amandan persiapan dalam menghadapi komplikasi dan tanda kehamilanbagi ibu hamil sehingga melahirkan bayi yang sehat.Manfaat program perencanaan persalinan dan pencegahankomplikasi mempunyai beberapa manfaat antara lainmempercepat berfungsinya desa siaga, meningkatkan cakupan pelayanan ANC sesuai standar, meningkatkan cakupan persalinan oleh tenaga kesehatan trampil, meningkatkan kemitraan bidan dan dukun, tertangganinya kejadian komplikasi secara dini, meningkatkan peserta KB pasca bersalin, terpantaunya kesakitan dan kematian ibu dan bayi, menurunnya kejadian kesakitan dann kematian ibu serta bayi.

Sedangkan dalam jurnal Melati mencoba mencari tahu hubungan dukungan sosial suami dengan motivasi dalam menjaga kesehatan selama kehamilan. Dalam jurnal Melati juga dijelaskan Suami adalah orang yang pertama dan utama dalam memberikan dorongan kepada istri nya sebelum pihak lain turut memberikan dorongan. Pada masa kehamilan kaum suami juga cenderung memberikan reaksi yang positif serta memberikan dorongan atau dukungan terhadap istrinya. Suami yang meberikan dukungan yang dibutuhkan ibu selama hamil selama kehamilan tentunya akan meberikan manfaat yang positif bagi ibu hamil. Ibu hamil akan merasa nyaman, aman, tentram dan tentunya akan menjadi termotivasi untuk menjaga kesehatan selama kehamilannya. Dukungan sosial melibatkan hubungan sosial yang berarti, sehingga dapat menimbulkan pengaruh positif bagi si penerimanya. Hubungan sosial dapat meningkatkan kesehatan dan kesejahteraan psikologis. Hubungan sosial juga mampu menolong individu mengurangi pengaruh yang merugikan dan dapat mempertahankan diri dari pengaruh negatif. Pada masa kehamilan dukungan sosial dari suami sangat diperlukan oleh ibu hamil, ibu hamil menjadi bahagia dan menghayati masa kehamilannya dengan tenang sehingga ibu dapat termotivasi menjaga kesehatannya. Selama kehamilan.

Berdasarkan hasil literatur review terhadap kedua jurnal diatas peneliti berasumsi bahwa kedua jurnal tersebut terdapat perbedaan dimana dalam jurnal Lestari ingin mencari tahu ada tidaknya hubungan pengetahuan ibu hamil tentang program perencanaan persalinan dan pencegahan komplikasi dengan pemilihan tempat persalinan sedangkan dalam jurnal Melati menjelaskan mencoba mencari tahu hubungan dukungan sosial suami dengan motivasi 
dalam menjaga kesehatan selama kehamilan.

2. Perbandingan Jurnal Kamidah (2018) dan Jurnal Jannah (2017)

Kedua jurnal tersebut memiliki perbedaan, dimana dalam jurnal Kamidah mencoba untuk mengetahui tentang Program Perencanaan Persalinan dan Pencegahan Komplikasi (P4K) dala upaya menurunkan angka kematian ibu dengan melakukan pendataan secara langsung. Dalam jurnal Kamidah juga dijelaskan Program Perencanaan Persalinan danPencegahan Komplikasi (P4K) merupakansalah satu upaya pemerintah dalam menurunkanAngka Kematian Ibu (AKI) di Indonesia. Setelah pendataan ibu hamil, tugasbidan selanjutnya adalah melakukanpemeriksaan ANC dan melakukankonseling tentang $\mathrm{P} 4 \mathrm{~K}$ yang meliputi HPL,pendamping persalinan, donor darah, dantransportasi dan persiapan persalinantermasuk biaya. Apabila ibu sudah diberikoseling dan stiker diisi oleh bidan makatindakan selanjutnya adalah penempelanstiker sebagai legalitas jika ibu sudahmendapat konseling. Hanya dari informasiyang diperoleh baik dari kader maupunbidan desa, untuk penempelan stiker adayang dilakukan oleh ibu hamil sendiri. Maksud penempelan stiker adalah legalitasinformasi bahwa dalam rumah tersebut adaibu hamil, selain itu juga sebagai mediainformasi kepada masyarakat sekitar untukikut berperan aktif memantau ibu hamil jika ada kegawatdaruratan, agar ibu segeramendapat pertolongan dengan cepat. Penempelan stiker inidilakukan oleh bidan desa dibantu olehkader, karena bila dilakukan oleh ibu hamilsendiri belum tentu masyarakat dapatterinformasi keberadaan ibu hamil dalamrumah tersebut, jika penempelan stiker inidilakukan ole bidan, bidan dapat langsungmemberi edukasi kepada keluarga danmasyarakat sekitar dengan tepat apa yangmenjadi tugas keluarga dan masyarakat.

Sedangkan dalam jurnal Jannah ingin mengetahui bagaimana peran suami dalam program Perencanaan Persalinan Dan Pencegahan Komplikasi (P4K) Pada Ibu Hamil. Dalam jurnal Jannah juga dijelaskan bahwa salah satu upaya terobosan untuk percepatan penurunan angka kematian ibu (AKI) adalah Program Perencanaan Persalinan dan Pencegahan Komplikasi (P4K). Kegiatan $\mathrm{P} 4 \mathrm{~K}$ dengan stiker juga merupakan salah satu instrumen yang efektif dalam mencapai sasaran SDGs terutama dalam hal penurunan AKI, yang telah terintegrasi sebagai satu kegiatan dari desa siaga. Program perencanaan persalinan dan pencegahan komplikasi (P4K) dapat dilakukan yaitu dengan cara pemasangan stiker $\mathrm{P} 4 \mathrm{~K}$ yang terdiri dari nama ibu, taksiran persalinan, penolong persalinan, tempat persalinan, pendamping persalinan, transportasi dan calon donor darah. Upaya penurunan angka kematian ibu dapat dilakukan dengan peningkatan cakupan dan kualitas pelayanan kesehatan ibu. Salah satu upaya yang dilakukan yaitu dengan program perencanaan persalinan dan pencegahan komplikasi (P4K) oleh Menteri Kesehatan pada tahun 2007. Upaya tersebut dilakukan dengan cara pemasangan stiker persalinan pada semua rumah ibu hamil yang merupakan terobosan dalam percepatan penurunan Angka Kematian Ibu (AKI) yang melalui kegiatan peningkatan akses pelayanan sekaligus merupakan kegiatan yang membangun potensi masyarakat khususnya kepedulian masyarakat untuk 
persiapan dan siaga dalam menyelamatkan ibu dan bayi baru lahir. Melalui P4K dengan stiker, diharapkan masyarakat dapat mengembangkan norma sosial. Bahwa cara yang aman untuk menyelamatkan ibu hamil, bersalin, nifas, dan perawatan bayi baru lahir yaitu dengan memeriksakan kehamilan, bersalin, perawatan nifas, dan perawatan bayi baru lahir ke bidan atau tenaga kesehatan yang terampil di bidang kebidanan. Sehingga dengan penempelan stiker P4K diharapkan dapat mencapai dan mewujudkan visi Departemen Kesehatan yaitu "Masyarakat Mandiri untuk Hidup Sehat.

Berdasarkan hasil literatur review terhadap kedua jurnal diatas peneliti berasumsi bahwa kedua jurnal tersebut terdapat perbedaan dimana dalam jurnal Kamidah mencoba untuk mengetahui tentang Program Perencanaan Persalinan dan Pencegahan Komplikasi (P4K) dala upaya menurunkan angka kematian ibu dengan melakukan pendataan secara langsung. Sedangkan dalam jurnal Jannah ingin mengetahui bagaimana peran suami dalam program Perencanaan Persalinan Dan Pencegahan Komplikasi (P4K) Pada Ibu Hamil.

3. Perbandingan Jurnal Aulia (2019) dan Jurnal Yasril (2019)

Kedua jurnal tersebut memiliki perbedaan, dimana dalam jurnal Aulia ingin mencari tahu bagaimana pemberian informasi terhadap pengetahuan ibu hamil tentang program perencanaan persalinan dan pencegahan komplikasi. Dalam jurnal Aulia juga dijelaskan bahwa peran bidan dalam pelaksanaan Program Persalinan Dan Pencegahan Komplikasi (P4K) yaitu bidan mendata ibu hamil, bidan bersama kader atau dukun melakukan kontak denga ibu hamil suami dan keluarga untuk sepakat dalam pengisian stiker termasuk pemakian $\mathrm{KB}$ pasca persalinan, bidan memberikan konselinng pada ibu hamil, suami dan keluarga tentang Program Perencanaan Persalinan Dan Pencegahan Komplikasi (P4K) terutama dalam menyepakati isi dalam stiker sampai dengan alat ontrasepsi pasca persalinan yang harus tercatat dalam amanahpersalinan yang dilakukan secara bertahap yang dipegang oleh petugas tenaga kesehatan dan buku KIA yang dipegang langsung oleh ibu hamil.Peran ibu hamil dalam pelaksanaan Program Perencanaan Persalinan Dan Pencegahan Komplikasi (P4K) yaitu terdatanya ibu hamil dan terpasangnya stiker P4K, adanya persalinan yang aman, adanya rencana untuk menggunakan alat kontrasepsi setelah melahirkan yang disepakati antara ibu hamil, suami, keluarga dan bidan, terlaksananya pengambilan keputusan yang cepat dan tepat bila terjadi komplikasi selama kehamilan, persalinan, dan nifas, serta meningkatkan keterlibatan tokoh masyarakat baik formal maupun non formal

Sedangkan dalam jurnal Yasril ingin mengetahui faktor yang berhubungan dengan P4K dengan kesiapan persalinan. Peran ibu hamil dalam pelaksanaan Program Perencanaan Persalinan Dan Pencegahan Komplikasi (P4K) yaitu terdatanya ibu hamil dan terpasangnya stiker P4K, adanya persalinan yang aman, adanya rencana untuk menggunakan alat kontrasepsi setelah melahirkan yang disepakati antara ibu hamil, suami, keluarga dan bidan, terlaksananya pengambilan keputusan yang cepat dan tepat bila terjadi komplikasi selama kehamilan, persalinan, dan nifas, serta meningkatkan keterlibatan tokoh masyarakat baik formal maupun non formal. Ibu hamil dan keluarganya 
mempunyai rencana persalinan dan keluarga berencana yang dibuat bersama dengan penolong persalinan, keluarga mempersiapkan persalinan baik secara material, dan persiapan lingkungan (sosial, budaya), suami yang dalam masa kehamilan sampai persalinan istrinya selalu berperan aktif dalam meningkatkan kesiapan ibu hamil dalam menghadapi persalinan menguraikan dalam menghadapi persalinan suami memiliki peran serta yang besar seperti menentukan persalinan ditolong oleh bidan atau dokter menabung untuk biaya persalinan, menanyakan ke bidan, dokter kapan perkiraan tanggal persalinan, meminta penjelasan dalam inisiasi menyusui dini dan ASI Eksklusif menyiapkan kendaraan jika sewaktu waktu ibu dan bayi perlu segera ke Rumah Sakit.

Berdasarkan hasil literatur review terhadap kedua jurnal diatas peneliti berasumsi bahwa kedua jurnal tersebut terdapat perbedaan dimana dalam jurnal Aulia ingin mencari tahu bagaimana pemberian informasi terhadap pengetahuan ibu hamil tentang program perencanaan persalinan dan pencegahan komplikasi. Sedangkan dalam jurnal Yasril ingin mengetahui faktor yang berhubungan dengan $\mathrm{P} 4 \mathrm{~K}$ dengan kesiapan persalinan.

\section{Perbandingan Jurnal Khairunisa (2019) dan Jurnal Dewi (2013)}

Kedua jurnal tersebut memiliki perbedaan dimana dalam jurnal Khairunisa mencoba mencari tahu bagaimana Program Perencanaan Persalinan Dan Pencegahan Komplikasi (P4K) dengan Pemilihan Penolong Persalinan di Puskesmas. Dalam jurnal Khairunnisa dijelaskan bahwa
Pelaksanaan P4K yang difasilitasi bidan di desa dalam rangka meningkatkan peran aktif suami, keluarga dan masyarakat dalam merencanakan persalinan yang aman dan persiapan menghadapi komplikasi bagi ibu hamil, penggunaan $\mathrm{KB}$ pasca persalinan termasuk perencanaan dalam rangka meningkatkan cakupan dan mutu pelayanan kesehatan bagi ibu. Menginvestaris atau mendata ibu hamil dengan stiker, setiap kehamilan sampai dengan persalinan dan nifas dapat berjalan dengan aman dan selamat sehingga tidak terjadi kematian merupakan bentuk dari pelaksanaan Program Perencanaan Persalinan dan Pencegahan Komplikasi.

Sedangkan dalam jurnal Dewi ingin mencari tahu pengetahuan ibu hamil tentang program perencanaan persalinan dan pencegahan komplikasi. Selain itu dalam jurnal Dewi juga mejelaskan bahwa program Perencanaan Persalinan dan Pencegahan Komplikasi (P4K) adalah suatu kegiatan yang difasilitasi oleh Bidan di Desa dalam rangka peningkatan peran aktif suami, keluarga dan masyarakat dalam merencanakan persalinan yang aman dan persiapan menghadapi komplikasi pada ibu hamil, termasuk perencanaan pemakaian alat kontrasepsi pasca persalinan dengan menggunakan stiker sebagai media notifikasi sasaran untuk meningkatkan cakupan dan mutu pelayanan kesehatan bagi ibu dan bayi baru lahir. Melalui P4K dengan stiker yang ditempel dirumah ibu hamil, maka setiap ibu hamil akan tercatat, terdata dan terpantau secara tepat. Stiker P4K berisi data tentang: nama ibu hamil, taksiran persalinan, penolong persalinan, tempat persalinan, pendamping persalinan, transport yang digunakan dan calon donor darah. 
Dengan data dalam stiker, suami, keluarga, kader, dukun, bersama bidan di desa dapat memantau secara intensif keadaan dan perkembangan kesehatan ibu hamil, untuk mendapatkan pelayanan yang sesuai standar pada saat antenatal, persalinan dan nifas, sehingga proses persalinan sampai nifas termasuk rujukannya dapat berjalan dengan aman dan selamat, tidak terjadi kesakitan dan kematian ibu serta bayi yang dilahirkan selamat dan sehat.Program Perencanaan Persalinan dan Pencegahan Komplikasi (P4K) salah satu program untuk mendukung desa siaga yang diarahkan pada konsep persiapan persalinan dan kesiagaan menghadapi komplikasi (Amin, 2009). Program Perencanaan Persalinan dan Pencegahan Komplikasi (P4K) merupakan suatu upaya kesehatan untuk menurunkan kasus komplikasi dan kematian akibat komplikasi pada ibu hamil, dalam hal ini bidan diharapkan dapat membuat perencanaan persalinan disetiap pemeriksaan kehamilan atau antenatal care ibu hamil.Tujuan adanya P4K yaitu untuk meningkatkan angka persalinan oleh tenaga kesehatan terlatih sehingga menurunkan angka kematian pada ibu, serta meningkatkan pelayanan ibu hamil agar melahirkan dengan aman dan selamat.

Berdasarkan hasil literatur review terhadap kedua jurnal diatas peneliti berasumsi bahwa kedua jurnal tersebut terdapat perbedaan dimana dalam jurnal Khairunisa mencoba mencari tahu bagaimana Program Perencanaan Persalinan Dan Pencegahan Komplikasi (P4K) dengan Pemilihan Penolong Persalinan di Puskesmas. Sedangkan dalam jurnal Dewi ingin mencari tahu pengetahuan ibu hamil tentang program perencanaan persalinan dan pencegahan komplikasi.

\section{DAFTAR PUSTAKA}

Aulia. 2019. Pemberian informasi terhadap pengetahuan ibu hamil tentang program perencanaan persalinan dan pencegahan komplikasi.

BPM Soraya. 2020. Jumlah ibu hamil tahun 2017-2018. Palembang

Budiman. 2013. Kapita Selekta Kuesioner. Jakarta : Salemba Medika Delima. 2018.

Dewi. 2013.Gambaran Tingkat Pengetahuan Ibu Hamil Tentang Program Perencanaan Persalinan Dan Pencegahan Komplikasi Di Desa Pagedangan.

Dinkes Kota Palembang. 2018. Profil Kesehatan Kota Palembang.http://www.dinkes.kotap alembang.go.id, diakses 3 Februari 2020.

Dinkes Provinsi Sumatera Selatan. 2019. Profil Kesehatan Provinsi Sumatera Selatan.http://www.dinkes.prov.sum se.go.id, diakses 3 Februari 2020.

Hanum. 2017. Hubungan Pengetahuan Ibu Hamil Tentang Program Perencanaan Persalinan Dan Pencegahan Komplikasi Dengan Pemilihan Tempat Persalinan.

Jannah. 2017. Peran Suami Dalam Program

Perencanaan Persalinan Dan Pencegahan Komplikasi (P4K) Pada Ibu Hamil Di Puskesmas Sedayu II Bantulyogyakarta. Jurnal STIKES Achmad Yani Yogyakarta.

Kamidah. 2018. Program Perencanaan Persalinan Dan Pencegahan Komplikasi (P4K) Sebagai Upaya Menurunkan Angka Kematian Ibu. Jurnal STIKES Aisyiyah Surakarta.

Kemenkes. 2015. Pedoman Program Perencanaan Persalinan dan 
Pencegahan Komplikasi (P4K) dengan Stiker.

Khairunisa. 2019. Gambaran Program Perencanaan Persalinan Dan Pencegahan Komplikasi (P4K) dengan Pemilihan Penolong Persalinan di Puskesmas.

Lestari, Nur Sri. 2015. Tingkat pengetahuan ibu hamil tentang program perencanaan persalinan dan pencegahan komplikasi (P4K) di RB AN Nuur Surakarta. Jurnal STIKES Kusuma Husada Surakarta.

Melati. 2012. Hubungan Dukungan Sosial Suami Dengan Motivasi Dalam Menjaga Kesehatan Selama Kehamilan di Pekanbaru.

Notoatmodjo. 2018. Metode penelitian kesehatan. Jakarta : Rineka Cipta.

Nurrizka. 2018. Disparitas Kematian Maternal di Indonesia : Studi Ekologi dengan Analisis Spasial. Jurnal. MKMI Vol.14 No.2 Juni 2018.

Pramasanthi. 2016. Hubungan pengetahuan ibu hamil dan dukungan suami dengan kepatuhan melaksanakan program perencanaan persalinan dan pencegahan komplikasi $(P 4 K) d i$ Kota Salatiga. Jurnal Magister Kedokteran Keluarga Pasca Sarjana Universitas Sebelas Maret.

Riani. 2016. Hubungan Pengetahuan Ibu Hamil Dan Dukungan Suami Dengan Kepatuhan Melaksanakan Program Perencanaan Persalinan Dan Pencegahan Komplikasi (P4K) Di Kota Salatiga. Jurnal Universitas Sebelas Maret.

Sari, Afsah Novita. 2016. Analisis Jalur Faktor-Faktor yang Mempengaruhi Angka Kematian Ibu di Jawa Timur. Jurnal Universitas Pesantren Tinggi Darul Ulum.
Sibagariang. 2016. Kesehatan Reproduksi

Wanita Edisi Revisi . Yogyakarta :

PT. Pustaka Baru

Walyani, Elisabeth Siwi. 2008. Asuhan

Kebidanan pada Kehamilan.

Yogyakarta : PT. Pustaka Baru

Yasril. 2019. Faktor Yang Berhubungan

Tentang P4K dengan Kesiapan Persalinan Di Kelurahan Parupuk Tabing. 